Journal of Agricultural Scie
(TarimBilimleriDergisi)

\title{
Genoprotective Role of Purslane Methanol Extract Against Somatic Mutations Induced by Bifenthrin, a Third Generation Prethyroid Insecticide
}

\author{
Halit KIZILET $^{a}$ (D) , Handan UYSAL ${ }^{\text {b* }}$ (i) \\ ${ }^{a}$ Department of Cardiology, Erzurum Training and Research Hospital, 25100, Erzurum, TURKEY \\ ${ }^{b}$ Department of Biology, Faculty of Science, Atatürk University, 25240, Erzurum, TURKEY
}

ARTICLE INFO

Research Article

Corresponding Author: Handan UYSAL, E-mail:hauysal@atauni.edu.tr

Received: 20 February 2020 / Revised: 20 October 2021 / Accepted: 20 October 2021 / Online: 15 October 2022

Cite this article

KIZILET H, UYSAL H (2022). Genoprotective Role of Purslane Methanol Extract Against Somatic Mutations Induced by Bifenthrin, a third Generation Prethyroid Insecticide. Journal of Agricultural Sciences (Tarim Bilimleri Dergisi), 28(4):583-591. DOI: 10.15832/ankutbd.883842

\section{ABSTRACT}

In this study, in vitro and in vivo genotoxic effects of Bifenthrin (BIF), an important insecticide used in agricultural production, storage and processing, were investigated. The genoprotective properties of purslane (Portulaca oleracea L.) against the genotoxic effects of BIF were also determined by using the methanol (POmet) extract of this plant. In vivo experiments were performed with somatic mutation and recombination test (SMART) in Drosophila melanogaster. In in vitro studies, human peripheral blood cultures were prepared and different concentrations of BIF were applied to lymphocyte cells in accordance with the procedure of both the micronucleus (MN) and sister chromatid exchange (SCE) assay. The results obtained from all applied tests showed that BIF is genotoxic and induces chromosomal mutations. Later, another experiment was conducted and it was determined that the genotoxic effects of BIF were reduced with POmet $(1: 1 \mathrm{v} / \mathrm{v})$. This result, which was observed in all in vivo and in vitro tests, shows that purslane plant is a potent radical scavenger. Due to the healing properties of POmet, gas chromatography-mass spectrometry (GS-MS) method was used to determine the components in its content. Some of the components found in the highest ratio in this extract are $\gamma$-sitosterol $(21.86 \%), 13$ docosenamide, $(13.30 \%)$, palmitic acid $(12.85 \%)$, stigmasteol $(6.64 \%)$, campesterol $(5.69 \%)$, linoleicacid $(5.46 \%)$ and 2-methyl-1-hexadecanol $(3.88 \%)$.

Keywords: Drosophila melanogaster, Portulaca oleracea, Household insecticides, Human peripheral blood cultures, Gas chromotography-mass spectrometry

\section{Introduction}

In cases where agricultural products cannot be protected from diseases and pests, it becomes difficult to obtain healthy and sufficient food. Today, about $20 \%$ of the world's grain production is lost in the pre-harvest and post-harvest stages (Durmuşoğlu et al. 2010). One of the most important causes of these losses is pests that infect agricultural products and reduce yield. Pesticides are still used as the most effective method to fight with pests (Singh et al. 2020).

Pesticides are chemicals that are used to reduce the devastating effects of live forms on human and animals and on crops such as insects, rodents, wild weeds and fungi to damage inflicted or reduced nutritional value for the food resources production, storage and consumption (Meister 1999; Pazır \& Turan 2017). The pesticides group most widely used against pests are insecticides. Insecticides, which are a sub-group of pesticides used in many areas and providing control of harmful organisms, are chemical compounds used in agricultural production, in the storage of products and at homes for the purpose of killing harmful insects or preventing their reproduction. Insecticides are of great help in controlling harmful insects, which can increase product loss up to $100 \%$. However, since insecticides are not specific, they affect not only target organisms but also non-target organisms (Sayll \& Akman 1994; Özyurt et al. 2018). The unconscious use of insecticides has been shown to cause the destruction of beneficial organisms and endanger genetic diversity (Güngör 2003).

Wild plant and animal populations are decreased as a result of intensive use of insecticides in agriculture. Therefore, it was found to be endangered and started destruction of the beneficial organisms and genetic diversity. Insecticides are poisonous compounds that are purposely released into the environment for the specific purpose of killing insects. The broad use of insecticides represents a potential risk to humans and the environment (Cantelli-Forti et al. 1993; Tiryaki et al. 2010). 30\% of the world synthetic insecticides consist of pyrethroids and they are often preferred because despite being highly toxic to the target organisms, they are less toxic to birds and mammals (Mazmanc1 et al. 2008). Pyrethroid is an organic compound similar 
to natural pyrethrins formed by pyrethrum flowers (Chrysanthemum cinerariaefolium and C. coccineum). Pyrethroids are now the bulk of commercial house hold insecticides (Robert 2002; Dev 2017).

Bifenthrin (BIF), a member of the synthetic pyrethroid family of pesticides, is a third generation insecticide used extensively in agricultural production. This group of pyrethroids is not found naturally and is more resistant to light and exhibits higher toxic activity (Mokrey \& Hoagland 1989). BIF, with a half-life of approximately 7 days to 8 months, is insoluble in water or very slightly soluble, leaving a lot of residues in the soil (EXTOXNET 1996). In our country and in the world, they are used especially against aphids, fire ants, lice, fleas, spiders, ticks and flies, against ornamental plants, hops, raspberry, corn and cotton pests, as well as in homes, workplaces and schools (EPA 2010).

DNA disruption and oxidative stress play an important role in numerous cancers and pathological disorders, including carcinogenesis and aging (Soltani et al. 2009; Jacobsen-Pereira et al. 2018). Numerous experiments have shown that plantderived natural compounds demonstrate defensive behaviors against genotoxicity caused by oxidative stress (Plazar et al. 2008; El-Nekeety et al. 2017; Rahmouni et al. 2018). Fruits and vegetables include many types of phytochemicals with antioxidant, anti-mutagenic and anti-carcinogenic properties (Arora et al. 2002; Shahidi \& Ambigaipalan 2015; Janet al. 2018). Despite the development of medical science in a tremendous way in the $20^{\text {th }}$ century, plants are still used in traditional medicine (Jain et al. 2007; Izquierdo-Vega et al. 2017).

Purslane (Portulaca oleracea L.) is a wide spread wild edible plant with green leaves and is used as a medicinal plant. It is used as salad, vegetable and medicinal plants in all parts of the world. Purslane contains more omega-3 fatty acids ( $\alpha$-linolenic acid in particular) than any other leafy vegetable plant. Since it is used to cure many diseases, the World Health Organisation named the plant "Global Panacea", which means "good for every disease" (K1zılet \& Uysal 2018).

In this study, the genoprotective of methanol extracts of purslane (POmet) against the possible genotoxic effects of BIF were investigated. BIF is a powerful insecticide used against insects, their eggs and larvae, especially in agricultural areas and warehouses where agricultural products are stored. However, this insecticide is also used against insects in crowded environments such as homes, schools and workplaces where people live. In this case, humans as well as insects are exposed to insecticides in both agricultural and living areas. In this study, it was aimed to determine the genotoxic effects of BIF in both Drosophila melanogaster, an invertebrate insect species, and humans. The genotoxic effects of BIF were determined in Drosophila by in vivo Somatic Mutation and Recombination Test (SMART). In vitro Sister Chromatid Exchange Test (SCE) and Micronucleus Test were also used to determine the genotoxic effects of BIF in humans. POmet was applied to resolve the genotoxic effects of BIF in the highest application group of all three testing techniques. Additionally, the chemical contents of the methanol extracts of Portulaca oleracea was also defined by gas chromatography-mass spectrometry (GS-MS) method.

\section{Material and Methods}

\subsection{Chemicals}

The Bifenthrin (CAS No:82657-04-3, state powder purity 96\%), methanol (CAS No:67-56-1), dimethyl sulfoxide (CAS No:6768-5), ethyl methane-sulfonate (CAS No:62-50-0), 5-bromo-2-deoxyuridine (CAS No: 59-14-3), potassium chloride (CAS No: 7447-40-7), giemsa (CAS No: 51811-82-6), bisbenzimide H 33342 (CAS No:23491-52-3), sodium citrate (CAS No: 613204-3), sodium chloride (CAS No:7647-14-5), acetic acid (CAS No: 64-19-7), chromosome medium (CAS No: F 5023), colchicine (CAS No: L 6221) and cytochalasin-B (CAS No: 14930-96-2) were purchased from the Sigma-Aldrich Company while Drosophila Instant Medium has been acquired from the Carolina Biological Supplies Company.

\subsection{Preparation of the methanol extracts of Portulaca oleracea $L$.}

Purslane plant, which was determined to be used as an antigenotoxic agent in the experiments, was collected from the vicinity of Hasancik village in Adiyaman province and from an altitude of 600-900 meters. Methanol extract (POmet) was prepared with all of the above-ground organs of the purslane plant, such as stem, leaves and flowers, which were collected in its natural environment, during the flowering period and from lands far from agriculture (Uysal et al. 2015). POmet extract was dissolved with DMSO in the course of applications.

\subsection{GC-MS System and conditions}

Chromatographic analyzes were conducted on the Agilent 7820 A gas chromatography system. Various temperature programs have been studied for the GC-MS process. Components determined according to POmet spectrum. GS-MS analysis of POmet according to Kizilet et al. (2019).

\subsection{Experimental animals and laboratory condition}

The selected two Drosophila strains (mwh and $\mathrm{flr}^{3}$ ) were used in a previous study for somatic mutation and recombination test 
(SMART) (Kizilet \& Uysal 2019). The flies were kept according to Uysal et al. (2006) laboratory condition.

\subsection{Somatic mutation and recombination test (SMART)}

The method for somatic mutation and recombination test (SMART) was determined by Graf et al. (1984). According to this protocol, it was adapted to our laboratory conditions and applied. For this purpose, 4, 5, 6 and 7 ppm BIF application groups have been created and highest ( 7 ppm) BIF concentration was tested antigenotoxically with $1 \%$ POmet. The data is analyzed in compliance with the multiple-decision protocol of Frei \&Würgler (1995).

\subsection{Donors for peripheral blood assays}

All donors were determined according to Kizılet et al. (2019). Permission for the study was sought from the Erzurum Provincial Training and Research Hospital Local Ethics Committee (Number: 37732058-53/2467/BEAH KAEK 2015/9-67) and the rules of the committee were observed during the inquiry. Documented informed consent was received from all patients who engaged in the study.

\subsection{Sister chromatid exchange (SCE) assay}

To determine the genotoxic effects of BIF at different concentrations (50, 100, 250 and 500 ppm) and equal concentration of $500 \mathrm{ppm}$ BIF + POmet by SCE, 1-2.5 mL of human peripheral blood was added to $5 \mathrm{~mL}$ chromosome media. Different sets were prepared for each concentration and each donor. 5-bromo-2-deoxyuridine (BrdU) was added to all experiment sets at a final concentration of $10-4 \mathrm{M}$. All substances added to the tubes were sterilized to prevent contamination during the experimental stage. The experimental sets were incubated for 72 hours at $37{ }^{\circ} \mathrm{C}$ in dark incubators. At 70 hours of the experiment, colchicine was added to the medium at a final concentration of $0.5 \mu \mathrm{g} / \mathrm{mL}$ to stop the mitosis at the metaphase stage. At the end of the 72 hours incubation, the tubes were centrifuged and removed the supernatants. Hypotonic solution $(0.075 \mathrm{M} \mathrm{KCl})$ was added onto pellet and incubated for 30 minutes in dark incubator at $37{ }^{\circ} \mathrm{C}$. At the end of the time, the supernatant was removed after centrifugation. The remaining pellet was washed with a fixative consisting of a methanol/acetic acid $(3: 1 \mathrm{v} / \mathrm{v})$ mixture. This procedure was repeated three times.

Peripheral blood smears were then prepared from the remaining pellet and allowed to dry in the dark for 3 days. These preparations were stained according to Rooney \& Czepulkowski 1986 fluorescence plus Giemsa method. For this purpose, preparations were wetted with $0.5 \mu \mathrm{g} / \mathrm{mL}$ bisBenzimide (Hoechst 33342) for 20 minutes. Wet preparations were incubated for 1 hour under $366 \mathrm{~nm} \mathrm{UV}$. The preparations were then kept in a 2 X SSC (1:1 v/v $0.03 \mathrm{M}$ sodium citrate/0.03 M sodium chloride) solution in a $65{ }^{\circ} \mathrm{C}$ water bath for 1 hour. Finally, the preparations were stained with $5 \%$ giemsa.

Preparations were examined at $1000 \mathrm{X}$ magnification and sister chromatid changes were recorded on chromosomes in metaphases. The data obtained were analyzed with SPSS package program.

\subsection{Micronucleus (MN) assay}

Experimental setups for MN test were prepared by adding $5 \mathrm{~mL}$ chromosome medium to the test tubes containing $50,100,250$ and $500 \mathrm{ppm}$ BIF and equal concentrations of BIF+POmet (only for $500 \mathrm{ppm}$ BIF). All test tubes were allowed to incubate for 72 hours. In the experimental procedure, unlike SCE, BrdU was not added to the tubes. All solutions added to the tubes were sterilized to prevent contamination. Cytochalasin-B was added to the tubes at a final concentration of $3 \mu \mathrm{g} / \mathrm{mL}$ at $48 \mathrm{hours}$ of incubation (In order to have binucleated cells). The tubes were centrifuged at the end of the incubation and hypotonic fluid was applied to the pellet $(0.075 \mathrm{M} \mathrm{KCl})$ and incubated for 15 minutes at $37{ }^{\circ} \mathrm{C}$. At the end of the period, the tubes were centrifuged and remaining pellets washed with fixative solution $(1: 3 \mathrm{v} / \mathrm{v}$ acetic acid-methanol) 3 times. Then, the supernatant was discarded and smear preparations were made from the pellet and stained with $4 \%$ giemsa. 1000 cells from each preparation were counted and investigated under a light microscope at $400 \mathrm{X}$ magnification. The data obtained were analyzed with SPSS package program.

\section{Results}

\subsection{SMART findings}

The findings obtained from distilled water, dimethyl sulfoxide (DMSO), EMS, BIF and 7 ppm BIF+1\% POmet application groups for the normal wings $\left(\mathrm{mwh} / \mathrm{flr}^{3}\right)$ and serrate wings (mwh/TM3) phenotypes are shown in Table 1. As shown in Table 1, there were no significant differences between the values, which were obtained with distilled water and 1ppm DMSO applications for both normal and serrate wing phenotypes. When the BIF application groups (4, 5 and 6 ppm) were compared with the DMSO application group, inconclusive (i) results were observed for all spots, although increased mutation frequency in two phenotypes. 
Table 1- Wing spot test data obtained after exposure of BIF and BIF + POmet

\begin{tabular}{|c|c|c|c|c|c|c|c|c|c|c|c|c|c|c|c|c|c|}
\hline \multirow{2}{*}{$\begin{array}{l}\text { Compound } \\
\text { concentration } \\
(\text { ppm) }\end{array}$} & \multirow{2}{*}{$\begin{array}{l}\text { Number } \\
\text { of wings } \\
(N)\end{array}$} & \multicolumn{3}{|c|}{$\begin{array}{l}\text { Small single } \\
\text { spots }(1-2 \text { cells }) \\
(m=2)\end{array}$} & \multicolumn{3}{|c|}{$\begin{array}{l}\text { Large single } \\
\text { spots }(>2 \text { cells }) \\
(m=5)\end{array}$} & \multicolumn{3}{|c|}{$\begin{array}{l}\text { Twin spots } \\
(m=5)\end{array}$} & \multicolumn{3}{|c|}{$\begin{array}{l}\text { Total mwh } \\
\text { Spots } \\
(m=2)\end{array}$} & \multicolumn{3}{|c|}{$\begin{array}{l}\text { Total spots } \\
(m=2)\end{array}$} & \multirow{2}{*}{$\begin{array}{l}\text { Clone } \\
\text { induction } \\
\text { frequency } \\
(\text { CIF })\end{array}$} \\
\hline & & No & $F r$ & $D$ & No & $F r$. & $D$ & No & $F r$. & $D$ & No & $F r$ & $D$ & No & $F r$. & $D$ & \\
\hline \multicolumn{18}{|c|}{ Normal wings $\left(\mathrm{mwh} / \mathrm{flr}^{3}\right)$} \\
\hline Distilled water & 80 & 8 & $(0.10)$ & & 1 & $(0.01)$ & & 0 & $(0.00)$ & & 9 & $(0.11)$ & & 9 & $(0.11)$ & & 0.46 \\
\hline DMSO & 80 & 9 & $(0.11)$ & $\mathrm{i}$ & 1 & $(0.01)$ & $\mathrm{i}$ & 0 & $(0.00)$ & $\mathrm{i}$ & 10 & $(0.13)$ & $\mathrm{i}$ & 10 & $(0.13)$ & $\mathrm{i}$ & 0.51 \\
\hline EMS & 80 & 29 & $(0.36)$ & + & 11 & $(0.14)$ & + & 3 & $(0.04)$ & $\mathrm{i}$ & 39 & $(0.49)$ & + & 43 & $(0.54)$ & + & 2.00 \\
\hline $4 \mathrm{BIF}$ & 80 & 11 & $(0.14)$ & $\mathrm{i}$ & 0 & $(0.00)$ & - & 0 & $(0.00)$ & - & 11 & $(0.14)$ & $\mathrm{i}$ & 11 & $(0.14)$ & $\mathrm{i}$ & 0.56 \\
\hline $5 \mathrm{BIF}$ & 80 & 12 & $(0.15)$ & $\mathrm{i}$ & 1 & $(0.01)$ & $\mathrm{i}$ & 0 & $(0.00)$ & - & 13 & $(0.16)$ & $\mathrm{i}$ & 13 & $(0.16)$ & $\mathrm{i}$ & 0.66 \\
\hline $6 \mathrm{BIF}$ & 80 & 18 & $(0.23)$ & $\mathrm{i}$ & 0 & $(0.00)$ & - & 0 & $(0.00)$ & - & 18 & $(0.23)$ & $\mathrm{i}$ & 18 & $(0.23)$ & $\mathrm{i}$ & 0.92 \\
\hline $7 \mathrm{BIF}$ & 80 & 21 & $(0.26)$ & + & 0 & $(0.00)$ & - & 0 & $(0.00)$ & - & 21 & $(0.26)$ & + & 21 & $(0.26)$ & + & 1.07 \\
\hline 7BIF+\%1POmet & 80 & 12 & $(0.15)$ & $\mathrm{i}$ & 0 & $(0.00)$ & - & 0 & $(0.00)$ & - & 12 & $(0.15)$ & $\mathrm{i}$ & 12 & $(0.15)$ & $\mathrm{i}$ & 0.61 \\
\hline \multicolumn{18}{|c|}{ Serrate wings (mwh/TM3) } \\
\hline Distilled water & 80 & 7 & $(0.09)$ & & 0 & $(0.00)$ & & \multirow{8}{*}{\multicolumn{2}{|c|}{$\begin{array}{l}\text { Balancer } \\
\text { chromosome } \\
\text { TM3 does } \\
\text { not carry } \\
\text { the flr3 } \\
\text { mutation. }\end{array}$}} & & 7 & $(0.09)$ & & 7 & $(0.09)$ & & 0.35 \\
\hline DMSO & 80 & 7 & $(0.09)$ & $\mathrm{i}$ & 0 & $(0.00)$ & $\mathrm{i}$ & & & & 7 & $(0.09)$ & $\mathrm{i}$ & 7 & $(0.09)$ & $\mathrm{i}$ & 0.35 \\
\hline EMS & 80 & 19 & $(0.24)$ & - & 10 & $(0.13)$ & + & & & & 29 & $(0.36)$ & + & 29 & $(0.36)$ & + & 1.49 \\
\hline $4 \mathrm{BIF}$ & 80 & 9 & $(0.11)$ & $\mathrm{i}$ & 0 & $(0.00)$ & - & & & & 9 & $(0.11)$ & $\mathrm{i}$ & 9 & $(0.11)$ & $\mathrm{i}$ & 0.46 \\
\hline $5 \mathrm{BIF}$ & 80 & 9 & $(0.11)$ & $\mathrm{i}$ & 0 & $(0.00)$ & - & & & & 9 & $(0.11)$ & $\mathrm{i}$ & 9 & $(0.11)$ & $\mathrm{i}$ & 0.46 \\
\hline $6 \mathrm{BIF}$ & 80 & 10 & $(0.13)$ & $\mathrm{i}$ & 0 & $(0.00)$ & - & & & & 10 & $(0.13)$ & $\mathrm{i}$ & 10 & $(0.13)$ & $\mathrm{i}$ & 0.51 \\
\hline $7 \mathrm{BIF}$ & 80 & 11 & $(0.14)$ & $\mathrm{i}$ & 0 & $(0.00)$ & - & & & & 11 & $(0.14)$ & $\mathrm{i}$ & 11 & $(0.14)$ & $\mathrm{i}$ & 0.56 \\
\hline 7BIF+\%1POmet & 80 & 9 & $(0.11)$ & $\mathrm{i}$ & 0 & $(0.00)$ & - & & & & 9 & $(0.11)$ & $\mathrm{i}$ & 9 & $(0.11)$ & $\mathrm{i}$ & 0.46 \\
\hline
\end{tabular}

No: number of clones; Fr: frequency; D: statistical diagnosis +: positive; -: negative; i: inconclusive; m:multiplication factor

However, positive (+) results were observed in the highest BIF application group (7 ppm) due to the increase in the number of mutant clones for the normal wing phenotype $(\mathrm{P}<0.05)$. The clone induction frequency $(\mathrm{CIF})$ was also calculated according to the values obtained in this study. While the CIF value for $\mathrm{mwh} / \mathrm{flr}^{3}$ genotype (normal wing phenotype) in the application of 7 ppm BIF was 1.07, this value for the distilled water and DMSO control groups was measured as 0.46 and 0.51 (Table 1).

In addition, as shown in Table 1, 1\% POmet application reduced the frequency of mutations in all spots. Important variations were found between the values obtained with $7 \mathrm{ppm} \mathrm{BIF}$ and $7 \mathrm{ppm} \mathrm{BIF+1 \%} \mathrm{POmet} \mathrm{applications} \mathrm{for} \mathrm{both} \mathrm{normal}$ and serrate wing phenotypes $(\mathrm{P}<0.05)$. The CIF calculated as 1.07 for $\mathrm{mwh} / \mathrm{fl}^{3}$ genotype (normal wing phenotype) in the 7 ppm BIF application was found to be 0.61 for $7 \mathrm{ppm}+1 \%$ POmet application group. In the mwh/TM3 genotype (serrate wing phenotype), the CIF values were found to be 0.46 and 0.56 for the same application groups (Table 1). The decrease in CIF values in both normal and serrate wing phenotype was found statistically significant in $7 \mathrm{ppm}+1 \%$ POmet application group.

\subsection{SCE findings}

The SCE values, as a result of the application to human peripheral lymphocyte cells at 50, 100, 250 and 500 ppm BIF concentrations, were detected as $4.13 \pm 0.01,4.62 \pm 0.01,6.50 \pm 0.03$ and $7.05 \pm 0.02$ respectively. The results were statistically significant $(\mathrm{P}<0.05)$. These values were determined at $3.60 \pm 0.02$ for distilled water, $3.70 \pm 0.01$ for negative control group DMSO and 25.96 \pm 0.02 for EMS (positive control group) (Table 2). The difference between positive control group and negative control groups are statistically significant $(\mathrm{P}<0.05)$. While the replication index $(\mathrm{RI})$ values were accounted, these values decreased in all the application groups. The SCE value of BIF + POmet application at the rate of 1:1 to determine the therapeutic effect of purslane has decreased from $7.05 \pm 0.02$ to $3.80 \pm 0.01$ (Table 2). According to these values obtained from $\mathrm{BIF}+\mathrm{POmet}$ application, the decrease observed for SCE was statistically significant $(\mathrm{P}<0.05)$.

Table 2- Statistical significance of SCE induction after exposure to four concentrations of BIF and BIF + POmet

\begin{tabular}{lllll}
\hline Application Groups & Concentration & $R I$ & $\begin{array}{l}\text { SCE/cell } \\
\text { (Average })\end{array}$ & $\begin{array}{l}\text { Min.-Max. } \\
\text { SCE }\end{array}$ \\
\hline Distilled Water & - & $2.41 \pm 0.03$ & $3.60 \pm 0.02$ & $1-11$ \\
DMSO & $\% 2$ & $2.24 \pm 0.07$ & $3.70 \pm 0.01$ & $1-10$ \\
EMS & $2 \mathrm{mM}$ & $2.25 \pm 0.09$ & $25.96 \pm 0.02$ & $8-36$ \\
& 50 & $2.33 \pm 0.08$ & $4.13 \pm 0.01^{*}$ & $1-9$ \\
Bifenthrin (ppm) & 100 & $2.01 \pm 0.07^{*}$ & $4.62 \pm 0.01^{*}$ & $1-13$ \\
& 250 & $1.95 \pm 0.06^{*}$ & $6.50 \pm 0.03^{*}$ & $1-11$ \\
BIF + POmet & 500 & $1.90 \pm 0.04^{*}$ & $7.05 \pm 0.02^{*}$ & $4-13$ \\
\hline
\end{tabular}

*: Statistical difference is significant according to DMSO at the 0.05 level, **: Statistical difference is significant according to $500 \mathrm{ppm}$ BIF at the 0.05 level. 


\subsection{MN findings}

$\mathrm{MN}$ frequencies measured after exposure to varying concentrations $(50,100,250$ and 500 ppm) of BIF in human peripheral lymphocyte cells were detected as $1.100 \pm 0.73,1.475 \pm 0.85,1.850 \pm 0.44$ and $2.050 \pm 0.68$, respectively. These values were determined at $0.700 \pm 0.38$ for distilled water, $0.825 \pm 0.65$ for DMSO and $3.175 \pm 1.40$ for EMS (Table 3 ). The results were statistically significant between the application and all control groups $(\mathrm{P}<0.05)$. In addition, as shown in Table 3 NBI decreased in all BIF application groups. NBI was found to be $1.54 \pm 0.17$ in the DMSO negative control group. In the highest BIF application group, this value decreased to $1.25 \pm 0.18(\mathrm{P}<0.05)$.

In the BIF + POmet application, the MN frequency decreased from $2.050 \pm 0.68$ to $0.875 \pm 0.72(\mathrm{P}<0.05)$. In this application $\mathrm{NBI}$ value increased from $1.25 \pm 0.18$ to $1.56 \pm 0.19(\mathrm{P}<0.05)$.

Table 3- Statistical significance of MN induction after exposure to four concentrations of BIF and BIF + POmet

\begin{tabular}{|c|c|c|c|c|c|c|c|}
\hline $\begin{array}{l}\text { Application } \\
\text { Groups }\end{array}$ & Concentration & $\begin{array}{l}\text { Investigated of } \\
\text { binucleated } \\
\text { cells }\end{array}$ & $\begin{array}{l}\text { Numbe } \\
\text { within } \\
\text { (1) }\end{array}$ & $\begin{array}{l}\text { r of } N \\
\text { binuc } \\
(2)\end{array}$ & $\begin{array}{l} \\
\text { eat } \\
\text { (3) }\end{array}$ & $\begin{array}{l}M N \\
\text { frequency } \pm S . E .\end{array}$ & $\begin{array}{l}\text { Nuclear } \\
\text { division index } \\
(N D I) \pm \text { S.E. }\end{array}$ \\
\hline Distilled water & - & 4000 & 28 & - & - & $0.700 \pm 0.38$ & $1.52 \pm 0.15$ \\
\hline DMSO & $\% 2$ & 4000 & 33 & - & - & $0.825 \pm 0.65$ & $1.54 \pm 0.17$ \\
\hline EMS & $2 \mathrm{mM}$ & 4000 & 88 & 12 & 5 & $3.175 \pm 1.40$ & $1.48 \pm 0.18$ \\
\hline \multirow{4}{*}{ Bifenthrin (ppm) } & 50 & 4000 & 38 & 3 & - & $1.100 \pm 0.73$ & $1.55 \pm 0.13$ \\
\hline & 100 & 4000 & 51 & 4 & - & $1.475 \pm 0.85 *$ & $1.46 \pm 0.21$ \\
\hline & 250 & 4000 & 66 & 4 & - & $1.850 \pm 0.44^{*}$ & $1.38 \pm 0.20^{*}$ \\
\hline & 500 & 4000 & 71 & 4 & 1 & $2.050 \pm 0.68 *$ & $1.25 \pm 0.18^{*}$ \\
\hline $\mathrm{BIF}+\mathrm{POmet}$ & $1: 1$ & 4000 & 35 & - & - & $0.875 \pm 0.72 * *$ & $1.56 \pm 0.19^{* *}$ \\
\hline
\end{tabular}

*: Statistical difference is significant according to DMSO at the 0.05 level, **: Statistical difference is significant according to 500 ppm BIF at the 0.05 level.

\section{4. $C$-MS findings}

In this study, the components found in P. oleracea were determined by GC/MS method and listed in Table 4.23 components $(99.305 \%)$ were identified for POmet. The most common compounds in POmet are $\gamma$-sitosterol (peak no. 22), 13docosenamide (peak no. 13), $(\mathrm{Z})$ and palmitic acid (peak no. 5). The total amount of these three compounds is $48.001 \%$. Compounds such as phytol, linoleic acid, campesterol and stigmasterol were also found in different rates in the content of POmet at All of these compounds induce antigenotoxicity. Therefore, POmet can be considered as a strong radical scavenger against BIF insecticide.

Table 4- Chemical compositions of the POmet

\begin{tabular}{|c|c|c|c|c|c|}
\hline $\begin{array}{l}\text { Peak } \\
\text { number }\end{array}$ & $\begin{array}{l}\text { Retantion } \\
\text { time(min) }\end{array}$ & Component & $\begin{array}{l}\text { Molecular } \\
\text { formula }\end{array}$ & $\begin{array}{l}\text { Molecular } \\
\text { weight }(\mathrm{g} / \mathrm{mol})\end{array}$ & $\begin{array}{l}\% \text { ratio in } \\
\text { total component }\end{array}$ \\
\hline 1 & 16.137 & $\begin{array}{l}\text { 2,4 dihydroxy-2,4,6-trimethylcyclohexylidene- } \\
\text { acetic acid 8-lactone }\end{array}$ & $\mathrm{C} 11 \mathrm{H} 16 \mathrm{O} 3$ & 196.10 & 2.034 \\
\hline 2 & 16.727 & 2-cis-9-octadecenloxyethanol & $\mathrm{C} 20 \mathrm{H} 40 \mathrm{O} 2$ & 312.30 & 0.863 \\
\hline 3 & 16.856 & Hexahydrofamecyl acetone & $\mathrm{C} 18 \mathrm{H} 36 \mathrm{O}$ & 268.27 & 1.067 \\
\hline 4 & 18.188 & Palmitic acid methyl ester & $\mathrm{C} 17 \mathrm{H} 34 \mathrm{O} 2$ & 270.25 & 0.768 \\
\hline 5 & 19.104 & Palmitic acid & $\mathrm{C} 16 \mathrm{H} 32 \mathrm{O} 2$ & 256.24 & 12.848 \\
\hline 6 & 21.420 & Phytol & $\mathrm{C} 20 \mathrm{H} 40 \mathrm{O}$ & 296.30 & 4.101 \\
\hline 7 & 22.121 & Linoleic acid & $\mathrm{C} 18 \mathrm{H} 32 \mathrm{O} 2$ & 280.24 & 5.455 \\
\hline 8 & 29.612 & Behenicalchol & $\mathrm{C} 22 \mathrm{H} 46 \mathrm{O}$ & 326.35 & 2.008 \\
\hline 9 & 30.026 & Dipalmitin & $\mathrm{C} 35 \mathrm{H} 63 \mathrm{O} 5$ & 568.50 & 1.301 \\
\hline 10 & 30.481 & Diisoactyl phthalate & $\mathrm{C} 24 \mathrm{H} 38 \mathrm{O} 4$ & 390.27 & 2.352 \\
\hline 11 & 31.281 & Docosyl acetate & $\mathrm{C} 24 \mathrm{H} 48 \mathrm{O} 2$ & 368.36 & 2.745 \\
\hline 12 & 32.264 & 2-methyl-1-hexadecanol & $\mathrm{C} 17 \mathrm{H} 36 \mathrm{O}$ & 256.27 & 3.880 \\
\hline 13 & 33.233 & 13-docosenamide,$(\mathrm{Z})=($ Erucylamide $)$ & $\mathrm{C} 22 \mathrm{H} 43 \mathrm{NO}$ & 337.33 & 13.297 \\
\hline 14 & 33.423 & 2-bromo octadecanol & $\mathrm{C} 18 \mathrm{H} 35 \mathrm{BrO}$ & 346.18 & 2.177 \\
\hline 15 & 33.870 & Methyl epoxystearate & $\mathrm{C} 19 \mathrm{H} 36 \mathrm{O} 3$ & 312.26 & 0.917 \\
\hline 16 & 34.069 & Dihyaroxanthin & $\mathrm{C} 17 \mathrm{H} 24 \mathrm{O} 5$ & 308.16 & 1.303 \\
\hline 17 & 35.163 & 14-octadecenal & $\mathrm{C} 18 \mathrm{H} 34 \mathrm{O}$ & 266.26 & 1.247 \\
\hline 18 & 36.502 & $\alpha$-tocopherol & $\mathrm{C} 29 \mathrm{H} 50 \mathrm{O} 2$ & 430.38 & 1.245 \\
\hline 19 & 37.714 & Campesterol & $\mathrm{C} 28 \mathrm{H} 48 \mathrm{O}$ & 400.37 & 5.692 \\
\hline 20 & 38.113 & Stigmasterol & $\mathrm{C} 29 \mathrm{H} 48 \mathrm{O}$ & 412.37 & 6.642 \\
\hline 21 & 38.245 & Ethyl iso-allocholate & $\mathrm{C} 26 \mathrm{H} 44 \mathrm{O} 5$ & 436.31 & 2.157 \\
\hline 22 & 38.949 & $\gamma$-sitosterol & C29H50O & 414.38 & 21.856 \\
\hline 23 & 39.467 & Olean-12-en-3-one & $\mathrm{C} 30 \mathrm{H} 48 \mathrm{O}$ & 424.37 & 3.350 \\
\hline \multicolumn{5}{|c|}{ Total component percentage ratio } & 99.305 \\
\hline
\end{tabular}




\section{Discussion}

Physical factors such as solar radiation, x-rays and a wide variety of chemicals can affect cellular DNA. Oxidative stress can cause damage to lipids, proteins, and nucleic acids, resulting in improvements in signal transduction path ways, gene expression, cell mutation, and cell death (Demirci et al. 2008; Popracet et al. 2017). Pesticides are a significant group of human-made hazardous chemicals. Their probable synergistic or antagonistic side effects on humans have not yet been thoroughly studied (Demsia et al. 2007). Over the three decades since the launch of the first compounds with adequate photostability for agricultural use, synthetic pyrethroids have been valuable instruments for pest control in agriculture, public health and a wide range of household applications.

However, pyrethroids are not only neurotoxic to plants, but also to mammals (Soderlund et al. 2002; Costa 2015). Synthetic pyrethroids are neuropoisons that function on axons in peripheral and central nervous systems by interfering with sodium channels in mammals or insects (IPCS 1990). BIF is chemically classified as a pyrethroid. BIF interferes with the nervous system of the insect when it is eaten or touched (Miller \& Salgado 1985; Yanget et al. 2018). It is more harmful to insects than it is to humans, since insects have lower body temperatures and smaller body sizes. Therefore, it can show toxic effects at high doses.

In this study, while 7 ppm BIF was showing genotoxic effects on D. melanogaster, upwards of 50 ppm BIF were showing genotoxic effects on human peripheral blood cells. In conclusion; the higher concentrations of BIF were caused by somatic mutation and chromosomal defects in this study. Our findings are in accordance with other research performed in a similar fashion.

BIF was determined reduce the motor activity in rats at high doses (Wolansky et al. 2007; Scollon et al. 2011). BIF alone is not harmful to rodent nerve cells at a concentration of 10-3 M. However, a house hold use substance containing BIF has been found to be neurotoxic at concentrations between 10-6 and 10-7 M. The house hold formulation of the BIF insecticide decreased the viability of rodent nerve cell cultures, while the BIF did not. Both the formulation and the active ingredient decreased the development of neuritis in vitro, although the effect of the formulation was more extreme (Tran et al. 2006). These findings indicate that inert ingredients would strengthen the developmental neurotoxic effects of BIF. According to Walker \& Keith (1992) evidence of mutagenic effects from exposure to BIF are inconclusive. Studies of mouse white blood cells were positive for gene mutation. However, other tests of BIF's mutagenic effects, including the Ames test and experiments in liver rat bone marrow cells, were negative.

Sadowska-Woda (2010) has shown that BIF-induced oxidative stress induces increased lipid peroxidation and reduced antioxidant function in human peripheral blood. DNA disruption and oxidative stress play an important role in numerous cancers and pathological disorders, including carcinogenesis and aging (Soltani et al. 2009; Birch-Machin \& Bowman 2016). There has lately been a great deal of interest in the anti-mutagenic and anti-carcinogenic ability of plant-derived compounds and natural food ingredients (Bhuvaneswari 2005; Xu et al. 2007; Shahidi 2009). The mechanism of defence of these structurally very diverse compounds may be multifactorial, since the anti-mutagenic behaviour of most of these chemicals is linked to their scavenging properties (Larson 1988). P. oleracea is a rich source of omega-3 fatty acids, gallotannins, kaempferol, quercetin, apigenin, and glutathione (Sharmaet et al. 2009; Gharneh \& Hassandokht 2012; Naeem \& Khan 2013). Purslane contains in large quantities 1-norepinephrine (in fresh leaf $0.25 \%$ ) that neurohormone of helpful to brain fatigue. It has the highest omega-3 fatty acid content of all leafy vegetables (Kumlay et al. 2010). Antioxidant and antimutagenic functions of extracts of $P$. oleracea have been previously demonstrated and are proposed to be linked to their constituents, such as A, B1, B2, $\mathrm{C}$, niasinamid, nicotinic acid, $\alpha$-tocopherol, $\beta$-carotene, $\beta$-alanin, $\beta$-cyanine, magnesium, calcium, potassium, iron, omega3 fatty acids, gallotannins, kaempferol, quercetin, apigenin, flavonoids, ascorbic acid and glutathione (Simopoulos 2004).

In our study was determined that POmet, which was used in the experiment, inhibited somatic mutation in D. melanogaster and decreased the SCE and MN rate in human peripheral lymphocytes. Our result is supported by similar studies of purslane. Water extract of purslane significantly inhibited the DNA breakage (Behravan et al. 2011) and it's leaves stems and roots showed very strong antioxidant at in vivo and in vitro experiments on rabbits (Yu et al. 2007). Yen et al. (2001) have demonstrated that $P$. oleracea extract has antimutagenic activity against 2-amino-3-methylimidazo (4,5-f) quinoline (IQ) as a mutagenagent.

In POmet sample (Table 4), 99.305\% of the total extract was identified, predominating $\gamma$-sitosterol (21.856\%), 13docosenamide, (Z) (13.297\%), palmitic acid (12.848\%), stigmasteol (6.642\%) campesterol (5.692\%), linoleic acid (5.455\%) and 2-methyl-1-hexadecanol $(3.880 \%)$.

$\beta$-sitosterol and $\gamma$-sitosterol are most widely found sterols in the plant. It has also been documented that the volume and function of components of the extrinsic apoptic pathway in human lung and breast adenocarcinoma cells can be impaired by $\gamma$ sitosterol (Balamurugan et al. 2011). $\gamma$-sitosterol and 13-docosenamide, (Z) also shows high antimicrobial activity (Kanimozhi \& Bai 2012; Rukshana et al. 2017). Palmitic acid is the most common saturated fatty acid present in animals and plants. It is the first synthesized fatty acid in the formation of fatty acids in living things and the longer fatty acids are produced from it. 
Palmitic acid, like other fatty acids, is not free in nature. Reduces hydrogen peroxide formation (Aydin 2009). Stigmasterol and campesterol are a group of phytosterols. Stigmasterol is an unsaturated plant sterol. It is also useful for the treatment of many tumours, including ovarian, lung, breast and colon cancers. It also has strong antioxidant, hypoglycaemic and thyroid inhibiting effects (Panda et al. 2009). Linoleic acid is an unsaturated essential fatty acid. Linoleic acid exhibits potent antioxidant activity as opposed to $\alpha$-tocopherol (vitamin E), a known antioxidant (Ha et al. 1990).

Consequently, the higher concentration of BIF caused somatic mutation and chromosomal defects in this study. As a result of our study, the increase in mutations in SMART, and SCE and MN in in vitro tests, respectively, can be assumed as a marker of damage in genetic material. As seen above in similar studies, this genetic damage is caused by oxidative stress. Our results and previously conducted studies indicate that the effect of natural components of purslane is radically scavenging on the genotoxicagent BIF. Additionally, the repair of this damage by POmet indicates that purslane can be a strong antigenotoxic agent. This scavenger effect is due to the high concentration on the content of the compound in POmet.

\section{References}

Arora A, Sairam R K \& Srivastava G C (2002). Oxidative stress and antioxidative systems in plants. Current Science 82: 1227-1238. https://www.jstor.org/stable/24107045

Aydın S (2009). The identification of antioxidant, antimicrobial effects and fatty acids composition of Terfezia boudieri chatin and Lactarius vellereus (Fr.). Master thesis (Published), Selçuk University, TR

Balamurugan R, Duraipandiyan V \& Ignacimuthu S (2011). Antidiabetic activity of $\gamma$-sitosterol isolated from Lippianodiflora L. in streptozotocin induced diabetic rats. European Journal of Pharmacology 667(1-3): 410-418.https://doi.org/10.1016/j.ejphar.2011.05.025

Behravan J, Mosafa F, Soudmand N, Taghiabadi E, Razavi B M \& Karimi G (2011). Protective effects of aqueous and ethanolic extracts of Portulacaoleracea L. Aerial parts on H2O2- induced DNA damage in Lymphocytes by comet assay. Journal of Acupuncture and Meridian Studies 4: 193-197.https://doi.org/10.1016/j.jams.2011.09.008

Bhuvaneswari V, Phil M, Abraham S K \& Nagini S (2005). Combinatorial antigenotoxic and anticarcinogenic effects of tomato and garlic through modulation of xenobiotic-metabolizing enzymes during hamster buccal pouch carcinogenesis. Nutrition 21: 726731.https://doi.org/10.1016/j.nut.2004.05.024

Birch-Machin M A \& Bowman A (2016). Oxidative stres and ageing. British Journal of Dermatology 175: 26-29. https://doi.org/10.1111/bjd.14906

Cantelli-Forti G, Paolini M \& Hrelial P (1993). Multiple end point procedure to evaluate risk from pesticides. Environmental Health Perspectives 101: 15-20.https://doi.org/10.1289/ehp.93101s315

Costa L G (2015). The neurotoxicity of organochlorine and pyrethroid pesticides. Handbook of Clinical Neurology 131: 13548.https://doi.org/10.1016/B978-0-444-62627-1.00009-3

Demirci M, Hiller K A, Boslb C, Gallerb K, Schmalzb G \& Schweiklb H (2008). The induction of oxidative stress, cytotoxicity, and genotoxicity by dental adhesives. Dental Materials 24: 362-371.https://doi.org/10.1016/j.dental.2007.06.009

Demsia G, Vlastosa D, Goumenoub M \& Matthopoulos D P (2007). Assessment of the genotoxicity of imidacloprid and metalaxyl in cultured human lymphocytes and rat bone-marrow. Mutation Research/Genetic Toxicologyand Environmental 634: 3239.https://doi.org/10.1016/j.mrgentox.2007.05.018

Dev S (2017). Insecticides of natural origin.1st Edition. Available on Taylor \& Francis eBooks, Routledge, London. ISBN 9783718659135

Durmuşoğlu E, Tiryaki O \& Canhilal R (2010). Pesticide Use, Residue and Persistence Problems in Turkey, In: VII. Türkiye Ziraat Mühendisliği Teknik Kongresi, 11-15 Ocak, Ankara, Bildiriler Kitabı 2: pp. 589-607 (In Turkish)

El-Nekeety A A, Abdel-Wahhab K G, Abdel-Aziem S H, Mannaa F A, Hassan N S \& Abdel-Wahhab M A (2017). Papaya fruits extracts enhance the antioxidant capacity and modulate the genotoxicity and oxidative stress in the kidney of rats fed ochratoxin A-contaminated diet. Journal of Applied Pharmaceutical Science 7(07): 111-121. DOI: 10.7324/JAPS.2017.70718

EPA (2010). Environmental Protection Agency. Bifenthrin Summary Document. http://www.regulations.gov/search/Regs/home.html

EXTOXNET (1996). Extension Toxicology Network. Pesticide Information Profiles - Bifenthrin. http://extoxnet.orst.edu/pips/bifenthr.htm

Frei H \& Würgler F E (1995). Optimal experimental design and sample size for the statistical evaluation of data from somatic mutation and recombination test (SMART) in Drosophila. Mutation Research 334: 247-258.https://doi.org/10.1016/0165-1161(95)90018-7

Gharneh H A A \& Hassandokht M R (2012). Chemical composition of some Iranian purslane (Portulacaoleracea) as a leafy vegetable in south parts of Iran. Acta Horticulturae 944: 41-44. DOI: 10.17660/ActaHortic.2012.944.4

Graf U, Würgler F E, Katz A J, Frei H, Juon H, Hall C B \& Kale P G (1984). Somatic mutation test in Drosophila melanogaster. Environmental and Molecular Mutagenesis 6: 153-188.https://doi.org/10.1002/em.2860060206

Güngör B Ö (2003). Agricultural pollution and removal methods, In: V. Ulusal Çevre Mühendisliği Kongresi, Ankara, 1- 4 Ekim 2003 (In Turkish)

Ha Y L, Storkson J \& Pariza M W (1990). Inhibition of benzo(a) pyrene-induced mouse forestomach neoplasia by conjugated dienoic derivatives of linoleic-acid. Cancer Research 50(4): 1097-1101

IPCS (International Programme on Chemical Safety) (1990). International Programme on Chemical Safety Environmental Health Criteria 98 Tetrametrin. World Health Organization, Geneva. https://www.who.int/ipcs/en/

Izquierdo-Vega J, Morales-González J, Sánchez Gutiérrez M, Betanzos-Cabrera G, Sosa-Delgado S, Sumaya-Martínez M, Morales-González Á, Paniagua-Pérez R, Madrigal-Bujaidar E \& Madrigal-Santillán E (2017). Evidence of some natural products with antigenotoxic effects. Part 1: fruits and polysaccharides. Nutrients 9(2): 102.https://doi.org/10.3390/nu9020102

Jacobsen-Pereira C H, DosSantos C R, Maraslis F T, Pimentel L, Feijó A J L, Silva C I,Medeiros G S, Zeferino R C, Pedrosa R C \& Maluf S W (2018). Markers of genotoxicity and oxidative stress in farmers exposed to pesticides. Ecotoxicology and Environmental Safety 148: 177183.https://doi.org/10.1016/j.ecoenv.2017.10.004

Jain S, Shrivastava S, Nayak S \& Sumbhate S (2007). Recent trends in Curcuma longa Linn. Pharmacognosy Reviews 1: 119-128

Jan S A, Shinwari Z K \& Malik M (2018). Antioxidant and anticancer activities of Brassica rapa: a review. Med Crave Online Journal of Biology and Medicine (MOJBM) 3(5): 175-178. DOI: 10.15406/mojbm.2018.03.00094

Kanimozhi D \& Bai V R (2012). Evaluation of antimicrobial activity of Cynodondactylon. International Journal of Research in Pharmaceutical Sciences (IJRPS) 2(2): 34-43 
Kizılet H \& Uysal H (2018). Induced Genotoxicity in Human Lymphocytes by Neonicotinoids. Cumhuriyet Science Journal 39(1): 201-210 (In Turkish). DOI: 10.17776/csj.406158

Kizılet H \& Uysal H (2019). Induced somatic mutation during chronic exposure of chlorfenson on Drosophila melanogaster Oregon R (wild type). Drosophila Information Service 102:4-8. https://www.ou.edu/journals/dis/DIS102/DIS102.pdf

Kizılet H, Yilmaz B \& Uysal H (2019). Herbal medicine against genotoxicity of dimethoate, an insecticide, in mammalian somatic cells. Heliyon 5(3): e01337. doi:10.1016/j.heliyon.2019. e01337

Kumlay A M, Yıldız Ö, Yurt B \& Zengin H (2010). Some wild edible plants consumed traditionally in IğdırTürkiye. 1. In: 1. Traditional Foods from the Adriatic to the Caucasus Symposium 15-17 April, Tekirdağ, pp. 904

Larson R A (1988). The antioxidants of higher plants. Phytochemistry 27: 969-978.https://doi.org/10.1016/0031-9422(88)80254-1

Mazmancı B, Tamer L \& Aşkın A (2008). Investigation of acute toxic effects of lambda-cyhalothrin in rats. Mersin Üniversitesi Săglık Bilimleri Dergisi 1: 15-9 (In Turkish). https://dergipark.org.tr/tr/pub/mersinsbd/issue/19517/207886

Meister R T (1999). Farm chemicals handbook '99. Meister Publishing Company. Willoughby, Ohio ISSN: 0430-0750

Miller T A \& Salgado V L (1985). The mode of action of pyrethroids on insects. In: J P Leahey (Eds), Pyrethroid Insecticides, Taylor \& Francis, London pp. 43-97

Mokrey L E \& Hoagland K D (1989). Acute toxicities offive synthetic pyrethroid insecticides to daphniamagna and ceriodaphniadubia. Environmental Toxicology and Chemistry 9: 1045-1051.https://doi.org/10.1002/etc.5620090811

Naeem F \& Khan S H (2013). Purslane (Portulacaoleracea L.) as phytogenic substance - a review. Journal of Herbs, Spices \& Medicinal Plants 19: 216-232 https://doi.org/10.1080/10496475.2013.782381

Özyurt E, Kizılet H \& Uysal H (2018). Bio-Interaction of Chlordane on Non-Target Organisms. Commagene Journal of Biology 2(1): 48-54 (In Turkish).https://doi.org/10.31594/commagene.418411

Panda S, Jafri M, Kar A \& Meheta B K (2009). Thyroid inhibitory, antiperoxidative and hypoglycemic effects of stigmasterol isolated from Butea monosperma. Fitoterapia 80(2): 123-126.https://doi.org/10.1016/j.fitote.2008.12.002

Pazır F \& Turan F (2017). Various removal methods of some pesticide residues in fruits and vegetables. Journal of Food and Health Science 3(3): 109-116 (In Turkish).doi: 10.3153/JFHS17014

Plazar J, Filipic M \& Groothuis G M (2008). Antigenotoxic effect of xanthohumol in rat liver slices. Toxicology in Vitro 22: 318327.https://doi.org/10.1016/j.tiv.2007.09.009

Poprac P, Jomova K, Simunkova M, Kollar V, Rhodes C J \& Valko M (2017). Targeting free radicals in oxidative stress-related human diseases. Trends in pharmacological sciences 38(7): 592-607 https://doi.org/10.1016/j.tips.2017.04.005

Rahmouni F, Saoudi M, Amri N, El-Feki A, Rebai T \& Badraoui R (2018). Protective effect of Teucriumpolium on carbon tetrachloride induced genotoxicity and oxidative stress in rats. Archives of Physiology and Biochemistry 124(1): 19.https://doi.org/10.1080/13813455.2017.1347795

Robert L (2002). Metcalf "Insect Control" in Ullmann's Encyclopedia of Industrial Chemistry" Wiley-VCH, Weinheim. doi:10.1002/14356007.a14_263

Rooney D E \& Czepulkowski B H (1986). Human Cytogenetics: a practicalapproach. First ed, IRL Press, Oxford, London

Rukshana M S, Doss A \& KumariPushpa Rani T P (2017). Phytochemical screening and GC-MS analysis of leaf extract of Pergulariadaemia (Forssk) Chiov. Asian Journal of Plant Science \& Research (AJPSKY) 7(1): 9-15

Sadowska-Woda I, Popowicz D \& Karowicz-Bilińska A (2010). Bifenthrin-induced oxidative stress in human erythrocytes in vitro and protective effect of selected flavonols. Toxicology in Vitro 24: 460-464.https://doi.org/10.1016/j.tiv.2009.09.024

Scollon E J, Starr J M, Crofton K M, Wolansky M J, DeVito M J \& Hughes M F (2011). Correlation of tissue concentrations of the pyrethroidbifenthrin with neurotoxicity in the rat. Toxicology 290: 1-6.https://doi.org/10.1016/j.tox.2011.08.002

Shahidi F \& Ambigaipalan P (2015). Phenolics and polyphenolics in foods, beverages and spices: Antioxidant activity and health effects-A review. Journal of Functional Foods 18: 820-897.https://doi.org/10.1016/j.jff.2015.06.018

Shahidi F (2009). Nutraceutical and functional foods: whole versus processed foods. Trends in Food Science and Technology 20: 376-387 https://doi.org/10.1016/j.tifs.2008.08.004

Sharma A, Vijayakumar M, Rao C V, Unnikrishnan M K \& Reddy G D (2009). Action of Portulacaoleracea against streptozotocin-induced oxidative stress in experimental diabetic rats. Journal of Complementary and Integrative Medicine 6: 1-12.https://doi.org/10.2202/15533840.1181

Simopoulos A P (2004). Omega-3 fatty acids and antioxidants in edible wild plants. Biological Research 37: $263-277$. http://dx.doi.org/10.4067/S0716-97602004000200013

Singh R, Kumar N, Mehra R, Kumar H \& Singh V P (2020). Progress and challenges in the detection of residual pesticides using nanotechnology based colorimetric techniques. Trends in Environmental Analytical Chemistry 26: e00086. https://doi.org/10.1016/j.teac.2020.e00086

Soderlund D M, Clarkb J M, Sheetsc L P, Mullind L S, Piccirilloe V J, Sargentf D, Stevensg J T \& Weiner M L (2002). Mechanisms of pyrethroid neurotoxicity: implications for cumulative risk assessment. Toxicology 171: 3-59.https://doi.org/10.1016/S0300$483 X(01) 00569-8$

Soltani F, Mosaffa F, Iranshahi M, Karimi G, Malekaneh M, Haghighi F \& Behravan J (2009). Evaluation of antigenotoxicity effects of umbelliprenin on human peripheral lymphocytes exposed to oxidative stres. Cell Biology and Toxicology 25: 291296.https://doi.org/10.1007/s10565-008-9083-9

Tiryaki O, Canhilal R \& Horuz S (2010). The use of pesticides and their risks. Erciyes University Journal of the Institute of Science and Technology 26(2): 154-169 (In Turkish). https://dergipark.org.tr/tr/download/article-file/236259

Tran V, Hoffman N, Mofunanaya A, Pryor S C, Ojugbele O, McLaughlin A, Gibson L, Bonventre J A, Flynn K \& Weeks B S (2006). Bifenthrin inhibits neurite outgrowth in differentiating PC12 cells. Medical Science Monitor 12: 57-62. https://www.medscimonit.com/abstract/index/idArt/445228/act/2

Uysal H, Kizilet H, Ayar A \& Taheri A (2015). The use of endemic Iranian plant, Echiumamoenum against the ethyl methanesulfonate and the recovery of mutagenic effects. Toxicology and Industrial Health 31(1): 44-51.https://doi.org/10.1177/0748233712468019

Uysal H, Şişman T \& Aşkın H (2006). Drosophila Biology and Crossover Methods (Extended $2^{\text {nd }}$ Edition). Atatürk University Publications, ISBN: 975-442-111-0, No: 941, 53 s, Erzurum, Türkiye

Walker M M \& Keith L H (1992). EPA's pesticide fact sheet database. CRC Press, Chelsea. ISBN 0-87371-663-9 
Wolansky M J, Mc Daniel K L, Moser V C \& Crofton K M (2007). Influence of dosing volume on the neurotoxicity of bifenthrin. Neurotoxicology and Teratology 29: 377-384.https://doi.org/10.1016/j.ntt.2007.01.007

Xu B J, Yuan S H \& Chang S K C (2007). Comparative studies on the antioxidant activities of nine common food legumes against copper induced human low-density lipoprotein oxidation in vitro. Journal of Food Science 72: 522-527. DOI: 10.1111/j.17503841.2007.00464.x

Yang Y, Wu N \& Wang C (2018). Toxicity of the pyrethroidbifenthrin insecticide. Environmental Chemistry Letters 16(4): 13771391.https://doi.org/10.1007/s10311-018-0765-0

Yen G C, Chen H Y \& Peng H H (2001). Evaluation of the cytotoxicity, mutagenicity and antimutagenicity of emerging edible plants. Food and Chemical Toxicology 39: 1045-1053.https://doi.org/10.1016/S0278-6915(01)00053-9

Yu Q, Wang X \& Xiong Z (2007). Comparative study of in vitro and in vivo anti-oxygen free radical effects of different parts of Portulacaoleracea L. Practical Preventive Medicine 2: 346-348

(C) 2022 by the author(s). Published by Ankara University, Faculty of Agriculture, Ankara, Turkey. This is an Open Access article distributed under the terms and conditions of the Creative Commons Attribution (CC BY) license (http://creativecommons.org/licenses/by/4.0/), which permits unrestricted use, distribution, and reproduction in any medium, provided the original work is properly cited. 